\title{
A Evasão na Perspectiva de quem Persiste: um Estudo sobre os Fatores que Influenciam na Decisão de Evadir ou Persistir em Cursos de Licenciatura em Física Pautado pelos Relatos dos Formandos ${ }^{1}$
}

\section{Dropout from the Perspective of Persistent Students: a Study on the Factors that Influence the Decision to Drop out or Stay in Physics Teacher Education Courses Based on the Reports of Students in Their Last Term}

\author{
Letícia Tasca Pigosso \\ Bruna Schons Ribeiro \\ Brasil \\ Leonardo Albuquerque Heidemann \\ Brasil \\ Brasil
}

Centrados no problema da evasão em cursos de licenciatura, investigamos o processo de tomada de decisão entre persistir ou evadir a partir de uma perspectiva pouco explorada na literatura: a dos que superaram as dificuldades e se graduaram. Como parte da primeira etapa de uma pesquisa-ação que tem como objetivo institucionalizar ações de combate à evasão nos cursos de licenciatura em Física da Universidade Federal do Rio Grande do Sul, entrevistamos doze formandos para investigar quais foram suas motivações para concluir o curso e de que modo a instituição pode fomentar a persistência dos demais alunos. Fundamentados no modelo de Tinto sobre persistência universitária e nas orientações metodológicas de Yin, concluímos que são elementos importantes para fomentar a persistência dos estudantes: i. as suas crenças sobre suas competências para suprirem as demandas do curso (crenças de autoeficácia) e sobre o quanto se sentem pertencentes e valorizados no curso (senso de pertencimento), e ii. a construção de uma identificação com a profissão de professor.

Palavras-chave: evasão; licenciatura em física; persistência.

Focused on the issue of dropout in teacher education courses, we investigated the decision-making process involved in persisting or dropping out, from a perspective little addressed in the literature: that of those who overcame difficulties and graduated. As part of the first stage of an action research that aims to institutionalize actions to combat dropout in physics teacher education courses at Federal University of Rio

1 Uma versão preliminar deste estudo foi apresentada no XII Encontro Nacional de Pesquisa em Educação em Ciências, em 2019. 
Grande do Sul, we interviewed twelve students in their last term to investigate what were their motivations for completing the course and how the institution could enhance the persistence of other students. Based on Tinto's model of university persistence and Yin's methodological orientations, we found out that the following elements are important to foster student persistence: $i$. their beliefs about their competencies to overcome the demands of the course (self-efficacy) and how much they feel belonging and valued in the course (sense of belonging); and ii. the development of an identification with the teaching profession.

Keywords: dropout; physics teacher education course; persistence.

\section{Introdução}

Ingressar em um curso de Ensino Superior é ainda hoje um desafio para grande parte dos brasileiros. Ainda que políticas públicas de acesso à graduação - como a Lei n. 12.711 de $2012^{2}$, que estabelece cotas em universidades públicas para estudantes de escolas públicas - tenham colaborado de forma expressiva para amenizar as dificuldades dos menos favorecidos, os obstáculos enfrentados pelos que buscam ingressar em um curso de graduação podem ser muito significativos. O acesso ao Ensino Superior, para essas pessoas, não implica no fim das dificuldades para se alcançar a diplomação. Para muitos, os desafios enfrentados são insuperáveis, levando-os a evadir. Certo é que a intensidade das dificuldades engendradas por uma graduação pode variar sensivelmente dependendo da história de vida pregressa dos universitários. No entanto, estudos mostram que, independente da origem social ou econômica dos estudantes, as experiências vividas no curso superior são determinantes na decisão deles de evadir ou persistir nos cursos de graduação (Braga, Peixoto, \& Bogutchi, 2003; Daitx, Loguercio, \& Strack, 2016; Evangelho, Machado, Dorneles, \& Massoni, 2019; Lima Junior, Ostermann, \& Rezende, 2012; Palharini, 2004).

Bardagi e Hutz (2005) mostram, em uma revisão da literatura, que a falta de integração social na universidade, o descontentamento com questões institucionais e a falta de informações sobre o curso de graduação e a profissão desejada, por exemplo, são aspectos importantes no processo de decisão dos estudantes por evadir. Essa revisão mostra ainda que os estudos procuram elucidar o processo de decisão de evadir a partir da perspectiva dos que evadiram (e.g., Azzi, Mercuri, \& Moran, 1996; Cerqueira, 2003; Palma, Palma, \& Brancaleoni, 2005; Polydoro, 2000). No entanto, não identificamos na literatura investigações que tenham explorado esse problema do ponto de vista dos que persistiram. Entender os elementos que motivaram os formandos dos cursos de graduação possibilita uma compreensão dos aspectos não contemplados entre os que evadiram. Portanto, investigar a persistência é também uma alternativa para se investigar o processo de evasão. Além disso, as concepções dos formandos são importantes para

2 Disponível em: http://www.planalto.gov.br/ccivil_03/_ato2011-2014/2012/lei/112711.htm. Acesso em 26 de março de 2020. 
dirigir ações institucionais com o intuito de fomentar a persistência dos estudantes nesses cursos.

Procurando aprofundar a compreensão sobre os cursos de licenciatura em Ciências, investigamos neste artigo o fenômeno da evasão sob a ótica dos que superaram as dificuldades, ou seja, dos que persistiram. Procuramos entender como as experiências vividas na Universidade influenciaram na motivação para persistir de formandos de licenciatura em Física. Fundamentada no Modelo de Motivação da Persistência de Vincent Tinto (Tinto, 2017), esta pesquisa foi desenvolvida com os formandos da Universidade Federal do Rio Grande do Sul (UFRGS)3. Procuramos identificar elementos que podem ter contribuído para que esses estudantes cogitassem evadir, assim como os fatores que os levaram a superar essas situações, possibilitando uma compreensão mais profunda do processo de decisão entre evadir ou persistir em cursos de licenciatura em Física.

Um importante estudo que analisa o processo de evasão sob a perspectiva dos que evadiram foi desenvolvido por Lima Júnior (2013) no mesmo contexto da investigação relatada neste artigo, ou seja, no Instituto de Física da UFRGS (IF/UFRGS). Esse estudo teve por objetivo compreender dados que são bastante conhecidos pelos estudantes de Física da UFRGS: as altas taxas de evasão, que são refletidas no diminuto número de formandos em todos os semestres, tradicionalmente envolvendo cerca de cinco formandos de licenciatura em Física, em contraste ao ingresso de 30 alunos semestralmente. Lima Júnior (2013) constatou que algumas disposições compartilhadas no IF/UFRGS, como a valorização do autodidatismo e a desvalorização dos cursos de licenciatura em comparação ao bacharelado, são importantes para se compreender a decisão de evadir de muitos dos estudantes. Baseado nisso, o autor construiu uma agenda de mudanças institucionais para reverter o cenário da evasão dentro do referido Instituto.

A partir da publicação da Resolução $02 / 2015^{4}$ do Conselho Nacional de Educação, estabelecida em julho de 2015, que indicou mudanças necessárias aos cursos de licenciatura do Brasil, foi criado na UFRGS um Núcleo Docente Estruturante que direcionou seus esforços à estruturação de um currículo coerente com a Resolução e fundamentado na literatura de Ensino de Ciências, em consultas à comunidade e em estudos de viabilidade. A reformulação do currículo, que foi implementado no primeiro semestre letivo de 2018, desencadeou um cenário favorável, envolvendo, por exemplo: i) a admissão de três docentes especialistas na área de Ensino de Física, ii) o restabelecimento do Programa de Apoio à Graduação com a participação de quatro monitores trabalhando na implementação de metodologias ativas em disciplinas iniciais do curso, iii) esforços para a concentração dos horários das aulas dos ingressantes em um único turno e iv) instauração da Residência Pedagógica, que abriu diversas vagas de

3 Na UFRGS, são oferecidos dois cursos de licenciatura em Física: um diurno e outro noturno. Para mais detalhes, consulte http://www.ufrgs.br/ufrgs/ensino/graduacao/cursos/exibeCurso?cod_curso=1764. Acesso em 26 de março de 2020.

4 Disponível em: http://portal.mec.gov.br/docman/agosto-2017-pdf/70431-res-cne-cp-002-03072015-pdf/file. Acesso em 26 de março de 2020. 
bolsas para estudantes de licenciatura com a oportunidade de atuação dentro de escolas públicas.

Esse contexto de mudanças evidenciou a necessidade de avaliações sobre as consequências dessas transformações, e de ações pautadas pelo objetivo de se construir um ambiente institucional acolhedor para os estudantes, promovendo, entre outras coisas, uma cultura de valorização da colaboração (em oposição ao autodidatismo) e a construção de identidade própria para os cursos de licenciatura (em oposição à desvalorização destes). Centrado nesse objetivo, estabeleceu-se um grupo de pesquisaação que busca fomentar a persistência dos estudantes dos cursos de licenciatura em Física da UFRGS. Dirigidos metodologicamente pelas ideias de John Elliott (1991), que argumenta que, ainda que privilegie a prática, a pesquisa-ação não é ateórica, demandando a mobilização de teorias para guiarem as etapas previstas nas investigações, optamos por, no primeiro ciclo de pesquisa-ação, nos apoiar nas ideias de Vincent Tinto $(1975,2017)$. Tal decisão foi tomada tanto pelo fato de que as ideias de Tinto constituem um referencial teórico amplamente legitimado, sendo o mais utilizado mundialmente quando se investiga evasão universitária (Bardagi, \& Hutz, 2005), quanto pelo fato de o autor considerar as experiências vivenciadas pelo estudante dentro do ambiente universitário como um aspecto central na decisão de persistir, o que vai ao encontro dos resultados de Lima Júnior (2013) em seu estudo na UFRGS, e está em acordo com a escolha dos autores de direcionar as ações da pesquisa-ação a aspectos institucionais.

Com base nos motivos que levaram o grupo de pesquisa a estudar a questão da evasão dentro da UFRGS, além de tomada a decisão de focar em aspectos institucionais, buscou-se desenvolver uma pesquisa que fosse capaz de delinear ações a fim de motivar a persistência dos alunos, evitando assim recair em pesquisas puramente diagnósticas. De maneira simplificada, Elliott (1991) propõe que uma pesquisa-ação possui cinco etapas: identificação, reconhecimento, planejamento, implementação e revisão. A identificação é a construção da percepção de que existe algum problema que precisa ser resolvido em uma comunidade, ou uma prática que precisa ser melhorada; no reconhecimento, o pesquisador busca investigar o problema e o contexto em que ele se encontra, entender suas características e fornecer elementos para fundamentar as tomadas de decisões nos próximos passos; o planejamento envolve a formulação de ações com vistas à solução do problema / melhora da prática empregada, apoiada nos resultados da etapa de reconhecimento; a implementação se foca em pôr as ações planejadas em prática; por fim, a revisão é a análise das ações efetuadas e seus resultados.

Concordando com as ideias de Elliott (1991), entendemos que a produção de conhecimento científico também é primordial em uma pesquisa-ação. Em particular, a investigação relatada neste artigo está englobada na etapa de reconhecimento da pesquisa-ação desenvolvida na UFRGS. Buscando complementar os achados de Lima Júnior (2013), optamos por investigar a evasão de uma nova perspectiva: a dos que persistiram nos cursos de licenciatura em Física do Instituto e alcançaram a diplomação, incorporando uma nova visão para o reconhecimento da pesquisa-ação a 
ser desenvolvida. Buscamos compreender os fatores que os levaram a persistir, centrados na análise da motivação deles a partir dos seus próprios olhares, e entender como, apesar dos altos índices de evasão, eles foram capazes de completar a graduação.

Fundamentados no Modelo da Motivação da Persistência do Estudante de Tinto (2017), buscamos identificar como as experiências vividas pelos formandos das licenciaturas em Física do IF/UFRGS influenciaram três construtos que, segundo o autor, são primordiais na construção da motivação para persistir dos estudantes universitários, quais sejam: crenças de autoeficácia, senso de pertencimento e percepção de currículo. As crenças de autoeficácia refletem a percepção dos estudantes sobre suas capacidades para suprirem as demandas do curso; o senso de pertencimento sintetiza o sentimento dos estudantes sobre seus pertencimentos como membros de uma comunidade que valoriza suas participações na instituição; já a percepção de currículo é uma avaliação sobre o valor e/ou relevância dos estudos previstos no currículo dos seus cursos. Com isso, estabelecemos as seguintes questões de pesquisa: Como as experiências vividas pelos formandos dos cursos de licenciatura em Física influenciaram em suas crenças de autoeficácia, seus sensos de pertencimento e suas percepções de currículo durante suas trajetórias na Universidade Federal do Rio Grande do Sul? Como esses construtos evoluíram ao longo do curso e modificaram suas motivações?

No que segue, apresentamos uma breve análise da literatura sobre evasão universitária, o referencial teórico da investigação, a metodologia de pesquisa empregada, os resultados da investigação e as considerações finais do artigo.

\section{A evasão em cursos universitários}

O termo "evasão" é polissêmico (Bardagi, \& Hutz, 2005; Junior, \& Real, 2017; Tinto, 1975). Ele pode se referir à saída do estudante de um curso em particular, da universidade ou até mesmo do sistema universitário de ensino. Dessa forma, taxas ou números sobre evasão costumam ser de difícil interpretação, pois, dependendo do que se entende por evasão, ou até mesmo de como são mensuradas as taxas de evasão, podemos construir conclusões muito distintas (Silva Filho, Motejunas, Hipólito, \& Lobo, 2007). Por isso, pesquisas recentes preconizam a utilização de metodologias longitudinais nos trabalhos acadêmicos que tratam sobre evasão, ou seja, que acompanhem a trajetória dos estudantes dentro do curso (Junior, \& Real, 2017), para que seja possível se identificar características do processo de decisão da evasão, em oposição a estudos que se centram apenas em números que evidenciam essencialmente um produto desse processo. São elementos importantes, por exemplo, os motivos para a desistência, etapa do curso em que mais ocorre, e/ou o que poderia ser feito para mudar este cenário.

Visto que não há consenso sobre o que caracteriza a evasão universitária, a literatura se voltou a estudar o tema por meio de metodologias qualitativas com aqueles que evadiram, identificando os evadidos ou os alunos propensos à evasão como um grupo heterogêneo (Moura, \& Menezes, 2004). Bardagi e Hutz (2005), por meio de uma revisão da literatura, identificam diversos fatores relacionados com a decisão de evadir 
como:

“[...] pouca integração social à universidade (Cerqueira, 2003; Polydoro, 2000), aspectos da vida escolar anteriores à entrada no curso (deficiências escolares, falta de apoio à escolha) e expectativas não correspondidas (Cerqueira, 2003; Cunha et al., 2001; Magalhães e Redivo, 1998; Pacheco, Silva, Veloso, Silva et al., 2001), descontentamento com questões institucionais (horários das disciplinas, falta de cursos noturnos, impossibilidade de trabalhar e estudar ao mesmo tempo) (Lotufo, Souza Jr., Covacic e Brito, 1998; Magalhães e Redivo, 1998; Pacheco et al., 2001; Souza et al., 2001; Veloso e Almeida, 2001), mau desempenho no curso, reprovações e atraso (Cunha et al., 2001; Lotufo et al., 1998; Magalhães e Redivo, 1998), problemas financeiros (Lotufo et al., 1998; Pacheco et al., 2001; Palma et al., 2003; Souza et al., 2001), falta de informações sobre o curso e a profissão, gerando uma insatisfação geral (Cunha et al., 2001; Lotufo et al., 1998; Magalhães e Redivo, 1998; Pacheco et al., 2001; Prado, 1990; Souza et al., 2001), mau relacionamento professor-aluno (Cunha et al., 2001; Veloso e Almeida, 2001), entre outros" (2005, p. 285).

A literatura que trata sobre o tema demonstra diferenças culturais, socioeconômicas e até mesmo de gênero no padrão de evasão de cada instituição, porém Veloso e Almeida (2002) constatam que há uma certa universalidade no fenômeno da evasão, assim como a existência de um padrão no período em que o mesmo ocorre. Massi e Villani (2015), porém, se voltam para uma contratendência nessa universalidade. O curso de Química da UNESP (Universidade Estadual de São Paulo) de AraraquaraSP apresenta índices de evasão na licenciatura menores do que no bacharelado. Tal dado levou esses pesquisadores a buscar entender, por meio da Teoria de Integração do Estudante de Tinto (1975), as peculiaridades deste caso. Eles concluíram que as condições oferecidas pela Universidade e a conjugação da integração social e acadêmica são fundamentais para a maior permanência dos alunos, demonstrando a importância da ação da academia para a decisão de persistir dos estudantes.

Entretanto, apesar de existirem artigos como o de Massi e Villani (2015) e ser um consenso a necessidade de investigações longitudinais, ainda não são comuns pesquisas que têm como perspectiva o ponto de vista dos estudantes, como propõe Tinto (2017), em contraponto ao ponto de vista institucional. Inclusive, não são raros artigos fundamentados no Modelo de Integração do Estudante, modelo de Tinto (1975) sobre o processo de evasão construído na perspectiva das instituições universitárias, enquanto não identificamos pesquisas fundamentadas no Modelo de Motivação da Persistência do Estudante, o mais recente de Tinto (2017) sobre a evasão, que toma a perspectiva do estudante. Em parte, tal ausência pode ser explicada pelo fato de o modelo ser recente, mas vale ressaltar a importância de se trabalhar com um referencial que leva em consideração o ponto de vista de quem é afetado diretamente pelo processo de evasão.

O Modelo de Integração do Estudante, porém, ao ser usado no cenário brasileiro, apresenta a necessidade de ajustes, principalmente em se tratando do processo vocacional, fator que no cenário internacional não se mostra relevante (Bardagi, \& 
Paradiso, 2003). Esse processo evidencia a necessidade de se adicionar ao modelo uma dimensão vinculada com o compromisso com o curso, englobando a segurança profissional quanto à escolha do curso, que foi, em um estudo realizado na UNICAMP, um importante preditor da decisão de evadir dos universitários (Mercuri, \& Bridi, 2001; Mercuri, Moran, \& Azzi, 1995).

Grande parcela dos estudos acadêmicos sobre evasão apontam que esse fenômeno ocorre predominantemente nos primeiros semestres do curso (Braga et al., 2003; Silva Filho et al., 2007), de forma que pesquisas sobre evasão, em geral, têm como objetos de estudo alunos que ingressaram há poucos semestres e/ou os que já evadiram. É necessário, entretanto, se estudar também a outra face do processo de evasão, que é a análise dos fatores que levaram os formandos dos cursos a persistir. Inserida nesse cenário, nossa pesquisa foca em alunos que, apesar de todas as dificuldades que enfrentaram ao longo do curso, conseguiram superá-las e concluir a graduação, buscando estudar os fatores que motivaram a persistência em contraponto àqueles que buscam os fatores que motivaram a evasão. Assim, além de investigar acontecimentos que os fizeram pensar em desistir, pode-se identificar as motivações que os fizeram persistir.

Esses dois fatores - referencial teórico utilizado e objeto de estudo - tornam este trabalho inovador na pesquisa sobre evasão, podendo trazer resultados interessantes e importantes para aquelas comunidades acadêmicas que tiverem interesse em promover ações institucionais de incentivo à persistência. Além disso, a adaptação do modelo de Tinto (2017) ao contexto brasileiro é importante, tendo em vista que o sistema de educação superior brasileiro é distinto do sistema estadunidense. Nesse sentido, essa investigação contribui para preencher uma lacuna da área de pesquisa em Ensino de Ciências por meio de um estudo sobre o processo de evasão na perspectiva dos que persistiram, assim como com uma investigação pautada pelo modelo mais recente de Tinto (2017), possibilitando reflexões sobre a sua adequação para representar o contexto universitário brasileiro.

\section{Referencial Teórico: o Modelo da Motivação da Persistência do Estudante de Vincent Tinto}

Vincent Tinto é um sociólogo e teórico da educação que estuda há décadas a retenção de estudantes no ensino superior. É o referencial teórico mais utilizado no mundo quando se trata de evasão (Bardagi, \& Hutz, 2005) com diversos artigos sobre o tema (e.g., Tinto, 1997; Tinto, 1998; Tinto 2006) aprofundando e/ou atualizando seu modelo inicial sobre a retenção dos estudantes universitários (Tinto, 1975). A escolha por esse referencial se deu pela sua relevância no cenário educacional mundial e também por seu olhar recente estar voltado a aspectos relacionados com a interação dos estudantes com fatores institucionais que influenciam nas suas decisões. Tinto (2017) destaca tal decisão quando diz:

"Antes de começarmos uma discussão de implicações para a prática, vale a pena repetir que o modelo proposto aqui não se destina a ser um modelo completo de motivação, 
mas um que se concentra unicamente naquelas experiências no campus que moldam a motivação do aluno e que estão dentro da capacidade da instituição de influenciar. O foco é tanto na prática institucional quanto na teoria. $\mathrm{O}$ modelo não está preocupado com as experiências fora do campus que também podem influenciar a motivação" (2017, p. 6, tradução nossa).

O modelo de motivação de Tinto se alinha com o referencial metodológico escolhido principalmente devido ao foco nas práticas institucionais. A pesquisa-ação proposta por John Elliott (1991) consiste em ciclos que, ainda que estejam voltados à incorporação de valores às práticas, demandam a mobilização de teorias que orientem as suas etapas. Desta forma, fora necessária a inclusão de um referencial teórico já na etapa de reconhecimento do contexto do problema que fomenta a pesquisa-ação.

O modelo proposto por Tinto em 1975, chamado de Modelo de Integração do Estudante, relaciona aspectos pessoais e institucionais e explica que a decisão de evadir ou permanecer em um curso universitário não depende exclusivamente de características do estudante ou da instituição, mas sim da interação entre essas duas dimensões. Dessa forma, Tinto (1975) chama a atenção para dois elementos fundamentais na decisão de evadir ou não do estudante: a integração acadêmica e a integração social.

A integração acadêmica está relacionada com interações que o estudante tem com professores, funcionários e colegas nos ambientes formais da universidade. Grande parte da integração acadêmica é construída, por exemplo, nas interações ocorridas em sala de aula durante as atividades previstas nas disciplinas. Uma maior integração acadêmica depende ainda se, por exemplo, o estudante participa de eventos e programas promovidos pela instituição (como palestras, bolsas de iniciação científica ou extensão, etc.), ou se ele apresenta uma boa percepção do seu desempenho dentro do curso e do seu desenvolvimento como aluno e futuro profissional. Já a integração social diz respeito ao estudante estabelecer conexões informais com as pessoas com as quais convive no contexto universitário, como em conversas com os colegas sobre assuntos do dia a dia nos intervalos das aulas, e na participação de eventos sociais (na universidade ou fora dela), como festas, eventos esportivos ou culturais.

No modelo proposto por Tinto em 2017, que influenciou mais fortemente essa investigação, o autor redireciona o seu olhar da retenção dos estudantes pelas universidades para a persistência deles nos seus cursos, ou seja, afasta-se do ponto de vista institucional para analisar a evasão do ponto de vista dos estudantes. Nesse sentido, o autor destaca que "estudantes não querem ser retidos, eles querem persistir" (Tinto, 2017, p.1, tradução nossa). Sendo assim, não basta apenas que o aluno permaneça na universidade; ele precisa também estar motivado e comprometido em finalizar o curso, e é no que pode fomentar a motivação e o comprometimento que o grupo de pesquisaação que engloba essa investigação está concentrado.

O modelo de Tinto (2017) pode ser bem sintetizado pela Figura 1, que resume os fatores que são importantes na decisão do estudante de persistir ou não no curso. 


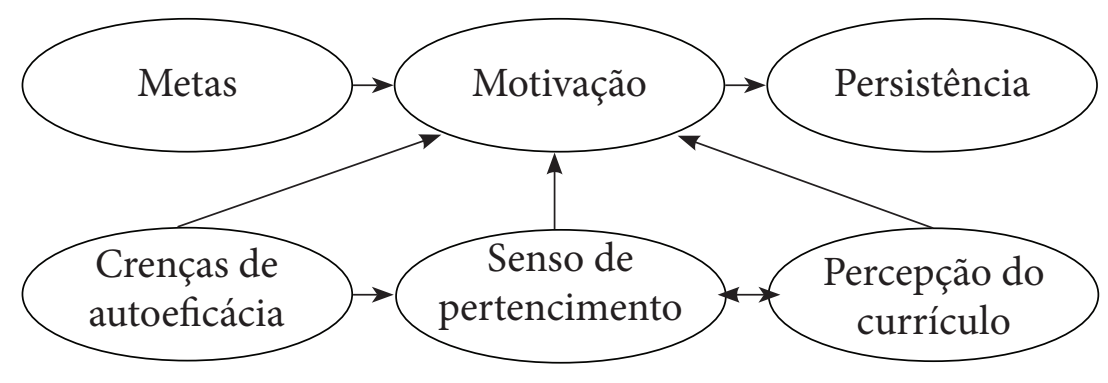

Figura 1. Modelo da Motivação da Persistência do Estudante (Tinto, 2017, p. 3, tradução nossa)

Como podemos constatar no esquema da Figura 1, a motivação do estudante é o principal preditor da sua persistência ou não no curso universitário. Entretanto, há vários fatores que influenciam nessa motivação e, portanto, refletem indiretamente na decisão tomada pelo aluno. Vamos discuti-las uma a uma, contextualizando-as dentro do IF/UFRGS.

Em primeiro lugar aparecem as metas, que englobam as características pessoais, como os objetivos de vida e as vivências anteriores dos estudantes. Para Tinto (2017), essas metas são fundamentais essencialmente no estabelecimento das motivações iniciais dos estudantes ao ingressarem em um curso superior. Ele afirma que "tais diferenças nas características e na intensidade das metas dos estudantes importam porque estudantes com diferentes metas e motivações para ir à universidade provavelmente serão afetados de maneiras distintas pelas suas experiências na universidade" (2017, p. 3, tradução nossa). Como exemplos de elementos desse construto, vamos supor duas situações que parecem ocorrer frequentemente nos cursos de Licenciatura em Física da UFRGS. Primeiro, um tipo de estudante que já tem professores na família, que teve bons exemplos de professores na sua vida estudantil, e que por esses e outros motivos percebeu que também deseja seguir essa profissão; esse tipo de estudante possui metas que vão motivá-lo a persistir no curso, pois se ele quer seguir a carreira docente, ele precisa concluir o curso de licenciatura. Já o segundo tipo de estudante é aquele que já entra no curso sabendo que não vai concluir - pois esse não é seu objetivo. Isso acontece com estudantes que desejam, por exemplo, estudar engenharia, ou até mesmo Bacharelado em Física, mas acabam optando por entrar na Licenciatura em Física por este curso possuir notas de corte $^{5}$ mais baixas que aqueles; assim, esses estudantes já vão cursando disciplinas de Física e Matemática básicas, que são comuns aos cursos citados, enquanto se preparam novamente para tentar ingressar nos cursos desejados. Sendo assim, esses estudantes não apresentam como meta concluir o curso de Licenciatura em Física, e isso influencia na sua não motivação para persistir. A partir da perspectiva de Tinto (2017), um estudante que, alinhado com o segundo perfil exemplificado, interrompe seu curso de licenciatura em Física para ingressar em um curso de engenharia não deve ter seu caso enquadrado

5 Nota de corte é o nome dado à nota obtida no vestibular ou no ENEM (Exame Nacional do Ensino Médio) pelo estudante que ingressou no curso com a nota mais baixa. Podemos entendê-la como uma "nota mínima" para entrar em determinado curso. 
como evasão, pois não possuía compromisso com o seu primeiro curso. Como estamos focados nos estudantes que concluíram suas graduações nesta investigação, ou seja, estamos focados em estudantes que tinham como meta concluir o curso de licenciatura em Física, não exploraremos esse construto com a mesma profundidade dos outros três que, segundo Tinto, influenciam a motivação dos estudantes para persistir, quais sejam: crenças de autoeficácia, senso de pertencimento e percepção de currículo. No âmbito da pesquisa-ação que engloba essa investigação, esses construtos são muito importantes porque podem ser alvos de ações institucionais voltadas para o fomento à persistência, tendo em vista que estão diretamente relacionados com experiências vividas no ambiente universitário.

Crenças de autoeficácia é um construto que se relaciona com a percepção que o estudante tem de si mesmo no que diz respeito à capacidade de suprir as demandas acadêmicas do curso, quer elas sejam em um curto espaço de tempo, como ir bem em uma prova, quer elas sejam mais duradouras, como avançar ao longo dos semestres. As crenças de autoeficácia não estão diretamente relacionadas com o real desempenho do estudante, mas sim com a percepção de que, mesmo apresentando um baixo rendimento eventualmente, ele pode vir a melhorá-lo, seja com mais dedicação ou com mais tempo de estudo, ou até mesmo com apoio psicológico. Sendo assim, “um dos desafios da educação não é somente ajudar os estudantes a construir habilidades acadêmicas necessárias, mas também reformular suas crenças a respeito de sua capacidade de obter sucesso" (Tinto, 2017, p. 4, tradução nossa).

O segundo construto, o senso de pertencimento, está relacionado com o sentimento que o estudante tem de fazer parte do ambiente universitário e, além disso, ser valorizado nesse ambiente. Sobre esse construto, Tinto (2017) afirma que "o que também é necessário [para fomentar a persistência] é que os estudantes passem a se ver como membros da comunidade de professores, funcionários e outros estudantes que valorizem sua participação, que eles importam e pertencem àquela comunidade" (p. 5, tradução nossa). Neste estudo, analisamos o senso de pertencimento em duas dimensões: uma social e uma acadêmica. Essa divisão é inspirada no primeiro modelo de Tinto (1975), e reflete o quanto o aluno se sente pertencente à esfera social - conversando informalmente com colegas e professores, participando de festas, eventos culturais e esportivos - e à esfera acadêmica - participando das aulas, dos programas ofertados pela universidade, de bolsas de extensão, iniciação científica ou à docência.

Um importante elemento do senso de pertencimento é que não basta estar presente nos ambientes; é preciso se sentir importante, valorizado e querido nesses ambientes. Por exemplo, quando um aluno falta uma aula e um colega o procura, essa ação pode elevar o senso de pertencimento desse aluno, pois ele pode se sentir importante naquele espaço. Ou então quando o orientador elogia o trabalho que o seu aluno de iniciação científica está desenvolvendo, ele se sente valorizado academicamente. Todos esses sentimentos podem ajudar a motivar o estudante a persistir no curso.

O terceiro construto, a percepção de currículo, reflete a concepção que o estudante 
tem sobre o currículo que está cursando e qual a importância dele para a sua formação. Sobre isso, Tinto (2017) afirma: "Embora o que constitui qualidade e relevância está longe de ser simples, a questão subjacente é clara: os estudantes precisam sentir que os conteúdos a serem aprendidos são de suficiente qualidade para que justifique seu tempo e esforço." (p. 6, tradução nossa).

Cabe destacar que "currículo" aqui não pode ser entendido de forma restrita, englobando apenas as disciplinas cursadas, mas também por quem elas foram lecionadas, de que maneira, em que momento, etc. Tinto (2017) afirma: "Percepções da qualidade e da relevância do currículo refletem uma complexa interação entre uma variedade de questões incluindo metodologias de ensino dos professores, percepção da qualidade da instituição, e também preferências e valores do estilo de aprendizagem do estudante." (p. 6, tradução nossa).

Ou seja, se o estudante percebe que as disciplinas são desconectadas ou que não seguem uma ordem adequada, que elas não o preparam devidamente para a carreira profissional, que os professores não se empenham em ministrar boas aulas ou então que determinados assuntos que deveriam ser estudados não o são, por exemplo, ele acaba se desmotivando por entender que não vai construir uma formação alinhada com as suas expectativas.

Por isso, o currículo, da perspectiva de Tinto (2017), precisa estar bem estruturado, a fim de que os estudantes entendam os propósitos aos quais ele serve e vejam sentido no curso que estão fazendo. É importante salientar que a reforma curricular implementada em 2018 nos cursos de licenciatura do IF/UFRGS, contexto dessa investigação, envolve diversas mudanças que permitem que os alunos tenham uma percepção mais positiva do currículo, proporcionadas inclusive pela contratação de professores especialistas na área de Ensino de Física, mostrando o quanto os cursos de Licenciatura em Física da Universidade Federal do Rio Grande do Sul têm sido valorizados nos últimos anos. Além disso, a mudança de postura dos professores, como foi comentado acima, também estimula uma visão mais positiva do currículo, principalmente ao fazer conexões entre os conteúdos dados em sua disciplina com os abordados em outras disciplinas - mais avançadas ou não - ou então relações entre esses conteúdos, que algumas vezes são excessivamente teóricos e desvinculados da realidade, com situações reais e do cotidiano. Essas atitudes valorizam o que está sendo ensinado e, consequentemente, $o$ currículo como um todo. No entanto, é importante salientar que o objeto de pesquisa desta investigação é um grupo de formandos que ingressou nos cursos de licenciatura em Física anteriormente à implementação do novo currículo.

Crenças de autoeficácia, senso de pertencimento e percepção de currículo podem ser entendidos, a partir do modelo de Tinto (2017), como preditores da decisão de evadir ou de persistir. Isso significa que, quando os três construtos se encontram em níveis baixos, é mais provável (mas não uma regra) que o estudante não persista no curso. Por isso, nossa pesquisa foca em investigar quais fatores que podem contribuir para elevar os níveis desses três construtos, de forma a fomentar a persistência dos estudantes. 


\section{Metodologia de Pesquisa}

A pesquisa-ação nos moldes de John Elliott (1991) funciona como uma espiral, de modo que o reconhecimento do problema, ações sobre este problema e estudo baseado nas ações formam um primeiro ciclo da espiral, que segue em diversos ciclos de reconhecimento, ação e pesquisa. No projeto que engloba essa investigação, tomouse como primeiro trabalho de reconhecimento a tese de Lima Júnior (2013), sendo a reformulação curricular ocorrida em 2018 a primeira mudança dentro do IF/UFRGS frente ao problema que motiva a pesquisa-ação. Para dar sequência ao estudo, portanto, são necessários mais estudos de reconhecimento, e essa investigação contribui para preencher essa lacuna.

Optamos por realizar esse reconhecimento a partir da vivência daqueles que ultrapassaram as barreiras institucionais e concluíram a graduação no currículo antigo. Cabe destacar que outros estudos, que fogem do escopo deste artigo, estão sendo desenvolvidos com o objetivo de se acompanhar a trajetória dos ingressantes após a transformação curricular ocorrida em 2018 (e.g., Moraes, 2020). Buscamos, por meio das histórias dos formandos, identificar fatores que influenciaram as suas motivações de persistir ao longo do curso, e ações que o IF/UFRGS pode tomar para aprimorar a experiência dos que vivem o currículo atualmente, concordando com o referencial teórico utilizado para guiar as ações e análises.

Para que pudéssemos identificar as experiências positivas e negativas dos formandos decorrentes do currículo que viveram, além de todo o contexto social e acadêmico externo, escolhemos realizar entrevistas semiestruturadas, gravadas em áudio, de forma que pudéssemos, além de avaliar as crenças de autoeficácia, senso de pertencimento e percepção de currículo do sujeito, realizar uma análise em tempo real e dirigir a entrevista enunciando perguntas que trouxessem elementos não citados naturalmente pelos entrevistados. Foram feitas entrevistas com 12 formandos, sendo que quatro deles se formaram no primeiro semestre de 2018, e oito, no segundo semestre. Todos os estudantes que se formaram no ano de 2018 foram convidados a participar da investigação. Apesar dos nossos esforços, quatro dos licenciandos preferiram não nos conceder entrevista. Dos participantes, nove eram do sexo masculino e três eram do sexo feminino. A idade variava entre 20 e 35 anos, tendo média de 26 anos. As entrevistas tiveram duração de cerca de uma hora.

O guia das entrevistas semiestruturadas possuía 24 questões. Essas questões eram agrupadas em blocos relacionados aos três construtos do modelo de persistência de Tinto (2017), além de apresentar um bloco voltado exclusivamente para a experiência geral do curso (veja o guia no Apêndice A). Em função dos resultados das entrevistas realizadas no primeiro semestre de 2018, o guia das entrevistas realizadas no segundo semestre contou com um bloco que diz respeito a identificação com a profissão. Como exemplo, o guia da entrevista engloba questões como "Quais foram as disciplinas que você mais gostou? E quais menos gostou? Por quê?” (bloco sobre percepção de currículo) e "O que você considera como os pontos positivos e os pontos negativos da tua experiência? Por 
quê?” (bloco sobre a motivação de persistir).

No início de todas as entrevistas, era exposta uma explicação ao participante sobre a pesquisa desenvolvida, e solicitado que o formando manifestasse oralmente seu consentimento com a investigação, assim como foi solicitado que assinassem um termo de consentimento informado e esclarecido. Após gravadas em áudio, as entrevistas foram ouvidas e as partes consideradas mais relevantes, ou seja, as que evidenciavam algum elemento vinculado com um dos construtos do modelo de Tinto (2017), foram transcritas. Optamos por analisar esses fragmentos por meio das orientações de análise de dados qualitativos de Robert Yin (2015), que se mostram alinhadas com a perspectiva pragmática de pesquisa-ação assumida por Elliott (1991) . Portanto, as análises foram realizadas em cinco etapas, quais sejam:

i. Compilação: nessa etapa, os dados coletados foram organizados, de forma a filtrá-los, mantendo apenas aqueles que possuem alguma relevância para a pesquisa, o que constituirá o banco de dados da investigação. Essa etapa, nesta pesquisa, consistiu em ouvir as entrevistas e registrar, por escrito, quais trechos das falas dos entrevistados eram importantes dentro do referencial teórico de Tinto (2017).

ii. Desagrupamento: essa etapa se resume a separar os fragmentos selecionados na etapa de compilação em categorias. Essas categorias podem estar definidas previamente ou não, e os fragmentos podem ou não ser rotulados. Nesta pesquisa, a etapa de desagrupamento consistiu, em um primeiro momento, em analisar os fragmentos e rotulá-los de acordo com os três construtos do Tinto (2017). A análise dos dados evidenciou a necessidade de uma revisitação a essa etapa e o estabelecimento de mais dois rótulos relacionados com a qualidade de escolha dos entrevistados pelo curso de licenciatura em Física e a identificação deles com a carreira docente.

iii. Reagrupamento: nessa etapa, os fragmentos que compõem cada categoria são agrupados; ou seja, fragmentos de cada categoria, que antes estavam todos misturados com os outros dados, agora são colocados juntos e separadamente das demais categorias. Nesta pesquisa, os fragmentos referentes a cada construto, que antes estavam escritos por ordem cronológica da fala do entrevistado, passam a ser escritos separadamente por categoria.

iv. Interpretação: nesta etapa, analisa-se cada uma das categorias separadamente. A partir da análise de cada uma delas, e sempre dirigidos pelo referencial teórico utilizado, é possível inferir algumas ideias acerca de cada um desses grupos de fragmentos. Nesta pesquisa, essa etapa se deu a partir da leitura de cada uma das categorias, analisando-as com base no referencial de Tinto (2017) e registrando pequenas interpretações obtidas a partir das falas dos entrevistados.

v. Conclusão: essa etapa consiste em analisar as interpretações feitas no estágio anterior e chegar a conclusões - que podem ser gerais ou separadas para cada categoria. Nesta pesquisa, foi realizada uma leitura de todas as interpretações feitas, para todas as categorias, um entrevistado

6 Yin (2015) se assume como um teórico alinhado com uma perspectiva pragmática, o que o aproxima das ideias de Elliott (1991), que defende que o objetivo da pesquisa-ação deve ser a melhora da prática. 
de cada vez, e construiu-se, então, conclusões acerca de que fatores foram relevantes para que cada um dos entrevistados persistisse no curso.

É importante destacar que, para Yin (2015), ainda que a análise de uma pesquisa qualitativa envolva essas cinco etapas, elas não ocorrem necessariamente na ordem apresentada. Muitas vezes essas etapas precisam ser revisitadas, e a análise envolve, portanto, avanços e retrocessos. A análise dos 12 participantes do estudo possibilitou a construção da tabela que se encontra no Apêndice B, que sintetiza os elementos que fundamentaram as conclusões do estudo. No que segue, expomos os resultados da investigação.

\section{Resultados}

Podemos concluir da análise das entrevistas que todos os três construtos descritos no Modelo da Motivação da Persistência do Estudante (Tinto, 2017) foram importantes na decisão de persistir no curso para os entrevistados. Em alguns casos, até mesmo dois dos construtos se mostram muito significativos. Ao longo do texto os nomes dos entrevistados foram alterados, sendo atribuídos nomes fictícios a fim de manter o sigilo sobre a identidade dos participantes. Para mais detalhes, veja o Apêndice B. Destaca-se, no entanto, que o senso de pertencimento foi o construto mais relevante, sendo decisivo na escolha por permanecer no curso para seis dos entrevistados.

Outro elemento importante foi que o modelo de Tinto (2017), em função das diferenças entre os sistemas universitários brasileiro e estadunidense, parece não dar ênfase suficiente para um importante elemento identificado nas entrevistas realizadas: a identificação com a profissão de professor. Esse aspecto se mostrou determinante para a persistência de 3 dos 12 formandos entrevistados.

É interessante notar ainda que há uma variação grande com relação aos construtos que influenciam na diminuição na motivação para persistir; entretanto, é possível ver que alguns estudantes não apresentam apenas um ou dois construtos baixos, mas sim todos, assim como já aponta Tinto (2017):

"É possível que alguns estudantes persistam mesmo quando há um baixo senso de pertencimento ou percepção de relevância do currículo. Esse pode ser o caso quando a percepção de benefícios extrínsecos de receber um diploma acadêmico é suficientemente grande para garantir a conclusão" (p. 6, tradução nossa).

Frente a tal dado, pudemos concluir que os três construtos preditores se retroalimentam. Um construto desfavorável pode, portanto, contribuir para que todos se tornem desfavoráveis. Em determinado momento do curso, a estudante Caroline não se sentia mais identificada com o curso de Licenciatura em Física, em especial devido a sua percepção de currículo (ela gostaria de fazer pesquisa, mas não vislumbrava essa possibilidade na licenciatura). Ela disse: "no quarto semestre eu estava meio desmotivada com o curso; não estava entendendo muito bem o que eu estava fazendo. [...] Mas no quinto semestre eu fiz uma disciplina do Ensino de Física, e eu comecei a ver que existe uma 
tradição de pesquisa em Ensino de Física, me mostrando que eu posso ser pesquisadora na licenciatura além de ser professora". Com a percepção de currículo desfavorável, o seu senso de pertencimento também diminuiu, inclusive porque ela estava começando a trabalhar como bolsista de iniciação científica no Departamento de Astronomia da UFRGS, e considerando seriamente a mudança para o bacharelado, ou seja, seu senso de pertencimento acadêmico dentro da licenciatura se encontrava cada vez mais baixo. Por fim, com esses dois construtos já em baixa e com vontade de desistir do curso, suas crenças de autoeficácia também diminuíram, em virtude de sua desmotivação para continuar. Em resumo, ainda que possamos identificar um responsável para a diminuição da motivação do estudante, em certos casos podemos ter dois e até três construtos relevantes nessa diminuição.

Por fim, é importante analisarmos o que poderia ter estimulado a motivação dos estudantes, em especial para que possamos proporcionar isso aos alunos que estão ingressando no curso, e, assim, fomentar a persistência deles. São identificados como elementos importantes que poderiam fomentar a persistência dos estudantes a valorização dos cursos de Licenciatura em Física e a promoção do contato com alunos do Ensino Médio desde o começo do curso, lembrando que o primeiro (mas não único) objetivo da licenciatura é formar professores para a Educação Básica. Contudo, chama a atenção que o principal fator identificado entre os participantes como elemento para fomentar a persistência está a introdução de disciplinas de Ensino de Física (as especificamente promovidas pelo Instituto de Física, e não as conduzidas pela Faculdade de Educação) nos primeiros semestres do curso (ver Apêndice B). É praticamente unânime a opinião entre os formandos de que as disciplinas de Ensino de Física são as mais proveitosas e importantes dos currículos das Licenciaturas, e são elas que motivam muitos alunos a seguirem no curso e na profissão. Tal opinião pode ser exemplificada pela fala de Enzo, que diz: "Se houvesse estas disciplinas [do Ensino de Física] no início [do curso], eu teria dado mais valor ao curso".

Antes da reforma curricular implementada em 2018, ou seja, no currículo vivido pelos participantes deste estudo, as disciplinas sobre Ensino de Física só eram cursadas a partir do quarto semestre dos cursos de Licenciatura em Física. Os estudantes cursavam essencialmente disciplinas sobre Física (físicas gerais e experimentais), Matemática (cálculos, vetores e equações diferenciais) e Educação (políticas públicas, psicologia da educação e história da educação). Entretanto, como as maiores taxas de evasão ocorrem nos primeiros semestres do curso (Braga et al., 2003; Silva Filho et al., 2007), disciplinas sobre Ensino de Física poderiam atuar como motivadoras para a persistência dos alunos que pensam em evadir, e não apenas daqueles alunos que já chegaram pelo menos na metade do curso e que dificilmente vão desistir. Para isso, disciplinas específicas do Ensino de Física precisavam ser inseridas nos primeiros semestres das Licenciaturas em Física, o que efetivamente foi realizado na reforma curricular implementada em 2018, incorporando as disciplinas "Introdução à Física" e "Tendências Atuais na Física e no 7 Um relato sobre a concepção da disciplina "Introdução à Física" como uma ação de combate à evasão nos cursos de Licenciatura em Física da UFRGS pode ser consultado em Heidemann, Giongo e Moraes (no prelo). 
seu Ensino" já no primeiro semestre.

Buscando elucidar os resultados da investigação, expomos no que segue uma análise das entrevistas sintetizadas em termos dos construtos preditores da motivação segundo Tinto (2017).

\section{Senso de Pertencimento}

Este é o construto que se mostrou mais relevante para os nossos entrevistados. Englobando a relação entre os estudantes e seus colegas e professores, além de dar conta da relação deles com o ambiente universitário, o senso de pertencimento pode ser separado em senso de pertencimento social e acadêmico. Enquanto o social diz respeito a se o aluno se sente pertencente a um ciclo de amigos feito na Universidade, se ele vê os seus professores como acolhedores e se ele se considera bem-vindo na academia, o acadêmico engloba o pertencimento do aluno no ambiente universitário, por exemplo, se ele é bem visto nos corredores ou se faz parte de atividades extracurriculares, assim como a autoavaliação da sua participação nessas atividades.

Todos os entrevistados, ao constatar o senso de pertencimento como relevante na sua motivação para persistir, associavam-na ao senso de pertencimento social. $\mathrm{O}$ estudante Gustavo, por exemplo, pontua: "Os colegas foram o principal [na decisão de persistir]. Se eu fosse dividir o fato de eu ter permanecido, seria 50\% perseverança própria e 50\% o ombro amigo dos colegas". Tal passagem mostra que, apesar de possuir outros construtos relevantes, ele considera o senso de pertencimento social como o principal na sua decisão de persistir. O mesmo acontece com outros entrevistados, como Bruno, que nos momentos em que possuía sua crença de autoeficácia desfavorável, a sua relação com professores da instituição o manteve persistente. Gustavo pontua a necessidade de maior atenção da Instituição aos calouros, pelo fato de ter se sentido perdido ao ingressar na academia e por considerar que a sua desmotivação inicial poderia ser sanada por meio de melhor assistência da Universidade.

Apesar da existência de entrevistados em que as amizades se mostraram fundamentais, houve casos em que o senso de pertencimento social se mostrou um construto relevante para a diminuição da vontade de persistir, fato que aconteceu com Vicente. Ele afirma não ter construído amizades durante o tempo dentro da Universidade, mas destaca: "Eu acho que foi mais do ciclo social [não se sentir pertencente], [...] mas eu me sentia pertencente", mostrando que em momentos em que o construto social se mostrava desfavorável, a integração acadêmica dava conta de manter o construto em alta.

Os entrevistados que manifestaram que a identificação com a docência foi muito importante na persistência, iniciaram com uma integração social alta, mantendo por si só a vontade de persistir. Essa, porém, ao diminuir, foi contrabalanceada pela vontade de ser professor, fomentando a persistência até a conclusão do curso. O estudante Júlio

ao falar que "Eu pensava 'eu preciso desse diploma porque eu quero dar aula'. Se eu não tivesse isso na cabeça eu acho que não teria ficado no curso", resume a motivação dele e 
dos demais durante grande parte da graduação, mostrando a necessidade de se construir uma identidade da licenciatura dentro do Instituto de Física. A identificação com a profissão se mostrou parte da integração social também de Vitor, que durante grande parte da sua graduação possuía bolsas dentro da Faculdade de Educação, distanciandose do Instituto de Física. Ele afirma: "A bolsa que eu estou hoje [iniciação científica na área de Ensino de Física], além de me inserir no Instituto de Física, de me fazer pertencer a um grupo de pesquisa, hoje eu me sinto pertencente ao IF". Essa transcrição demonstra a importância da participação em atividades extracurriculares dentro do Instituto de Física, ajudando a aumentar a integração acadêmica do aluno assim como a sua identificação com a docência, corroborando com estudos como os de Oliveira e Dias (2014) e Bardagi e Hutz (2012).

\section{Percepção de Currículo}

A percepção de currículo é o construto que engloba a percepção do aluno a respeito do conteúdo que é tratado nas disciplinas, a forma como elas estão dispostas durante o curso, assim como a metodologia utilizada pelos professores. Em suma, este construto diz respeito ao currículo do curso e a percepção do aluno a respeito do alinhamento desse currículo com as suas expectativas de formação. Apesar de alguns alunos o terem como relevante na motivação de persistir, este é o construto que desmotivou os alunos de maneira menos impactante.

Apesar de não se mostrar tão relevante quanto os demais construtos, dez dos doze entrevistados relataram ter uma percepção de currículo desfavorável. O currículo dos cursos de licenciatura do IF/UFRGS, até a reforma de 2018, apresentava um modelo de currículo semelhante ao chamado modelo $2+2$, em que na primeira metade do curso, que demandava dois anos, os alunos são apresentados essencialmente aos conteúdos de Física básica e Matemáticas, e na segunda metade, que demandava mais dois anos, eles passam a ter contato com elementos do Ensino de Física. Essa divisão do currículo vem carregada de fortes críticas nas entrevistas, sendo uma das principais causas da baixa percepção de currículo dos participantes, como podemos exemplificar pela fala da estudante Vitória: "Um curso quebrado, dividido, era um curso que até a metade não tinha significado". Podemos concluir que, nos casos em que o indivíduo entrou no curso com a vontade de ser professor, esse modelo de currículo deixa uma parte da graduação sem ser conectada com a outra, corroborando os resultados de Braga et al. (2003) e Silva Filho et al. (2007), que mostram que a maior parte das ocorrências de evasão ocorrem nos primeiros semestres do curso.

O fato de os cursos de licenciatura do IF/UFRGS apresentarem apenas disciplinas semelhantes ao bacharelado no início causou a evasão do estudante Júlio, que ao ser perguntado pelo motivo que o levou a evadir, afirma: "Eu achava que ele [o curso] não estava me preparando pra escola.." Concluímos que, por mais que a percepção de currículo não se mostre tão relevante quanto os demais construtos na motivação para persistir, ele foi o ponto principal na decisão de uma evasão. Este entrevistado evadiu 
do curso e após o contato direto com a escola, retornou para a licenciatura, concluindo então o curso.

Além de possuir críticas a respeito da ordem das disciplinas no currículo, os formandos também se expressaram a respeito da forma como algumas disciplinas são conduzidas pelos professores, que se mostrou também um fator relevante na motivação dos alunos de persistir ou não com relação à percepção de currículo. Gustavo expressa, ao relatar a sua experiência no curso, que "Em sala de aula, foi uma tremenda perda de tempo essas cadeiras básicas [...], tudo que eu consegui captar, aprender, foi fora de sala de aula". Podemos concluir que, apesar de esse construto não ter influenciado na sua persistência com maior intensidade, ele foi relevante na sua graduação, alterando a ação dos demais construtos sobre o entrevistado.

\section{Crenças de Autoeficácia}

Enquanto o senso de pertencimento se mostra o construto mais relevante na decisão de persistir, as crenças de autoeficácia se mostram mais relevantes para diminuir a motivação dos entrevistados. Esse é o construto que, no modelo de Tinto (2017), diz respeito à percepção do estudante quanto a sua capacidade de realizar alguma tarefa, seja ela ampla, como terminar a graduação, ou mesmo particular, como responder corretamente a uma lista de exercícios proposta pelo professor. Quando o aluno não se sente capaz de realizar certas tarefas necessárias para atingir o seu objetivo de se graduar, ele passa a se sentir desmotivado, muitas vezes desistindo desse objetivo.

Nas entrevistas pudemos perceber que as disciplinas do início do curso se mostraram as mais relevantes na diminuição da vontade de persistir. $\mathrm{O}$ início dos cursos, no currículo em que os entrevistados estavam inseridos, apresentava as disciplinas básicas de matemática e física, ciclo tal que era extremamente semelhante ao curso de Bacharelado, e são as disciplinas dos cursos de licenciatura do IF/UFRGS que apresentam maior taxa de reprovação. Quatro dos cinco entrevistados que relataram a diminuição da motivação ficaram retidos nessas disciplinas e, no momento em que surgia a dificuldade de ser aprovado, todos passaram a se ver como incompetentes, como relata Vitória, que ao lembrar de quando foi reprovada em diversas disciplinas no início do curso, disse: "Eu ficava pensando [...] 'ai sou burra, vou desistir, não consigo"'. Esse relato evidencia que a reprovação e a retenção causam uma diminuição nas crenças de autoeficácia, conclusão que pode ser ilustrada também pela fala de Júlio: “Toda sexta-feira, quando eu precisava fazer os exercícios [de Física Geral], eu começava a chorar, porque eu não conseguia. [...] Eu ficava bem sério assim, pensando 'ai meu deus, eu não vou conseguir, vou reprovar"'.

Por outro lado, no momento em que os estudantes conseguiam superar as suas dificuldades a respeito das disciplinas, a crença de autoeficácia voltava a se mostrar favorável e, muitas vezes, influenciava a alta dos demais construtos, como podemos identificar na fala de Vitória, que, ao ser perguntada sobre qual foi a relevância de estudar as suas dificuldades e criar uma rotina de estudos, afirmou: "Facilitou. Eu vi que daquele jeito dava certo e então eu fiquei mais confiante [...] eu não ficava mais nervosa nas provas, 
minhas notas melhoraram, mudou da água pro vinho". Podemos concluir que, apesar de diminuírem a crença de autoeficácia no início, a existência das dificuldades deixou de atrapalhar no momento em que a entrevistada criou uma rotina de estudos, de modo que passou a confiar mais na sua capacidade de concluir a graduação.

\section{Considerações Finais}

Ao buscar responder como os construtos teorizados por Tinto (2017) influenciam na motivação de persistir e na trajetória de concluintes de um curso de licenciatura em Física, identificou-se que o modelo de Tinto (2017) precisa dirigir maior ênfase para alguns fatores que já se mostraram importantes em estudos anteriores quando se deseja utilizá-lo para representar o processo de evasão no contexto brasileiro com maior profundidade (Bardagi, \& Hutz, 2005). Neste estudo, evidenciamos a necessidade de se levar em conta a identificação com a profissão docente como um elemento primordial na decisão de persistir de estudantes de Licenciatura em Física. Identificouse, corroborando trabalhos como os de Lima Júnior (2013) e Daitx et al. (2016), que a motivação para persistir não se correlacionou com características socioculturais dos estudantes. Os resultados mostraram ainda que a motivação dos estudantes, acompanhando as transformações dos construtos preditores da motivação propostos por Tinto e do comprometimento com o curso, apresentam variações ao longo do curso. O desenvolvimento desta investigação, ao explorar limitações e potencialidades do modelo de Tinto (2017) contribui, principalmente, com a sequência das ações tomadas dentro do IF/UFRGS, e que podem, assim, contribuir com a área de Ensino de Física a médio e longo prazo.

Por meio da análise dos resultados se concluiu que os construtos principais na mudança da vontade de persistir dos alunos foram o senso de pertencimento e a crença de autoeficácia, de modo que podemos tomá-los como construtos pilares no fomento à persistência. Apenas um entrevistado que relatou passar por um momento em que esteve próximo de evadir não atribuiu sua falta de motivação para persistir a suas baixas crenças de autoeficácia para suprir alguma demanda do curso. Enquanto as crenças de autoeficácia baixas se mostraram como preditoras da evasão, o senso de pertencimento, somado à identificação com a profissão, foram os principais construtos que fomentaram a persistência dos entrevistados. Dessa forma, percebe-se a necessidade de construir uma rede de apoio entre os estudantes de modo que, no momento em que as crenças de autoeficácia diminuem a motivação, o senso de pertencimento com a Universidade, com os colegas e com atividades extracurriculares sejam capazes de fomentar a persistência.

A identificação com a profissão surgiu como uma união entre o senso de pertencimento e a percepção de currículo. Os entrevistados que a pontuaram como relevante para a persistência utilizaram a identificação com a profissão como uma forma de pertencimento ao curso; já aqueles que colocaram a identificação como importante por diminuir a motivação e aqueles que colocam como uma situação que os motivariam, citam a identificação como percepção de currículo, falando sobre a criação 
de uma identificação como papel dos professores e do curso. Oito dos entrevistados pontuaram a necessidade de antecipar as disciplinas específicas sobre o Ensino de Física no currículo dos seus cursos e de aumentar o contato dos licenciandos com a sala de aula, demonstrando a demanda que a identificação com a profissão provoca.

Levando em conta a demanda dos estudantes pela criação de uma identificação com a profissão de professor de Física, além de perceber a relação que o senso de pertencimento teve com os demais construtos na trajetória dos entrevistados, os resultados desta pesquisa serão de grande importância na escolha dos caminhos tomados pelo grupo de pesquisa-ação dentro do IF/UFRGS. A busca pela construção de uma identidade docente já iniciou com a mudança do currículo no ano de 2018, que passa a colocar os licenciandos em contato com a escola desde o primeiro semestre. $\mathrm{Na}$ busca por construir uma rede de apoio dentro dos cursos, estamos focando os esforços também no acolhimento dos calouros por meio do apadrinhamento e em um evento quinzenal para a divulgação dos trabalhos em Ensino de Física feitos por licenciandos.

\section{Agradecimentos}

Agradecemos à professora Eliane Angela Veit pelo incentivo ao trabalho, e aos pareceristas do artigo pela leitura crítica e pelas observações pertinentes que contribuíram para a melhora do nosso artigo.

\section{Referências}

Azzi, R. G., Mercuri, E., \& Moran, R. C. (1996). Fatores que interferem na decisão de desistência de curso no primeiro ano de graduação. In Anais do III Congresso Nacional de Psicologia Escolar. (p. 144-146). Rio de Janeiro, RJ.

Bardagi, M. P., \& Paradiso, Â. C. (2003). Trajetória acadêmica e satisfação com a escolha profissional de universitários em meio de curso. Revista Brasileira de Orientação Profissional, 4(1-2), 153-166.

Bardagi, M. P., \& Hutz, C. S. (2005). Evasão universitária e serviços de apoio ao estudante: uma breve revisão da literatura brasileira. Psicologia Revista, 14(2), 279-301.

Bardagi, M. P., \& Hutz, C.S. (2012). Rotina acadêmica e relação com colegas e professores: impacto na evasão universitária. Psico, 43(2), 174-184.

Braga, M. M., Peixoto, M. C., \& Bogutchi, T. F. (2003). A evasão no ensino superior brasileiro: o caso da UFMG. Avaliação: Revista da Avaliação da Educação Superior, 8(1), 161-189.

Cerqueira, T. C. S. (2003). Evasão do curso de Pedagogia da UnB: a interpretação do aluno evadido. In Anais do III Congresso Nortenordeste de Psicologia - Construindo a Psicologia Brasileira: Desafios da Ciência e Prática Psicológica (p. 282-283). João Pessoa, PB. 
Daitx, A. C., Loguercio, R. Q., \& Strack, R. (2016). Evasão e retenção escolar no curso de licenciatura em química do Instituto de Química da UFRGS. Investigações em Ensino de Ciências, 21(2), 153-178.

Elliott, J. (1991). Action Research for Educational Change. Philadelphia: Open University Press.

Evangelho, B., Machado, L., Dorneles, P., \& Massoni, N. (2019). Permanência no Curso de Licenciatura em Física da Unipampa Campus Bagé: um estudo exploratório com estudantes em fase final de curso. Revista Thema, 16(3), 501-515.

Heidemann, L. A., Giongo, S. L., Moraes, K. R. de M. (no prelo). Evadir ou persistir? Uma disciplina introdutória centrada no fomento à persistência nos cursos de licenciatura em Física. Revista Brasileira de Ensino de Ciências e Matemática.

Junior, J. D. S. S., \& Real, G. C. M. (2017). A evasão na educação superior: o estado da arte das pesquisas no Brasil a partir de 1990. Avaliação: Revista da Avaliação da Educação Superior, 22(2), 385-402.

Lei n. 12.711, de 29 de agosto de 2012 (2012). Dispõe sobre o ingresso nas universidades federais e nas instituições federais de ensino técnico de nível médio e dá outras providências. Diário Oficial da União. Brasília, DF.

Lima Junior, P., Ostermann, F., \& Rezende, F. (2012). Análise dos condicionantes sociais da evasão e retenção em cursos de graduação em Física à luz da sociologia de Bourdieu. Revista Brasileira de Pesquisa em Educação em Ciências, 12(1), 37-60.

Lima Júnior, P. R. M. (2013). Evasão do ensino superior de Física segundo a tradição disposicionalista em sociologia da educação. (Tese de doutorado em Ensino de Física). Instituto de Física da Universidade Federal do Rio Grande do Sul, Porto Alegre.

Massi, L., \& Villani, A. (2015). Um caso de contratendência: baixa evasão na licenciatura em química explicada pelas disposições e integrações. Educação e Pesquisa, 41(4), 975992.

Mercuri, E., Moran, R. C., \& Azzi, R. G. (1995). Análise de um estudo piloto sobre evasão de curso do primeiro ano de graduação de uma universidade pública estadual. In Anais da $18^{a}$ Reunião Anual da Associação Nacional de Pós-Graduação e Pesquisa em Educação (ANPPED). (p. 198). Caxambú, MG.

Moraes, K. R. de M. (2020). Uma investigação exploratória sobre as implicações das experiências de primeiro semestre de curso na decisão de evadir ou persistir dos estudantes de licenciatura em física da UFRGS. (Dissertação de Mestrado Acadêmico em Ensino de Física). Instituto de Física da Universidade Federal do Rio Grande do Sul, Porto Alegre.

Mercuri, E., \& Bridi, J. C. A. (2001). O desenvolvimento do compromisso com o curso como fator de permanência na universidade. In Resumos de Comunicações da XXXI Reunião Anual de Psicologia. (p. 190). Rio de Janeiro. 
Moura, C. B. D., \& Menezes, M. V. (2004). Mudando de opinião: análise de um grupo de pessoas em condição de re-escolha profissional. Revista Brasileira de Orientação Profissional, 5(1), 29-45.

Oliveira, C. T., \& Dias, A. C. G. (2014). Dificuldades na trajetória universitária e rede de apoio de calouros e formandos. Psico, 45(2), 187-197.

Oliveira, T. E. de. (2016). Aprendizagem de física, trabalho colaborativo e crenças de autoeficácia: um estudo de caso com o método team-based learning em uma disciplina introdutória de eletromagnetismo. (Dissertação de Mestrado Acadêmico em Ensino de Física). Instituto de Física da Universidade Federal do Rio Grande do Sul, Porto Alegre.

Palharini, F. de A. (2004). Elementos para a compreensão do fenômeno da evasão na UFF. Avaliação: Revista da Avaliação da Educação Superior, 9(2), 51-80.

Palma, A. M. P. V., Palma, S. P. V., \& Brancaleoni, A. P. L. (2005). Prevenção à evasão no ensino superior: necessária implementação de orientação profissional a graduandos em desligamento. In M. C. P. Lassance, A. C. Paradiso, M. P. Bardagi, M. Sparta, \& S. L. Frischenbruder (Org.), Intervenção e compromisso social - Orientação profissional teoria e técnica (pp. 303-317). São Paulo, SP: Vetor.

Polydoro, S. A. J. (2000). O trancamento de matrícula na trajetória acadêmica do universitário: condições de saída e retorno à instituição. (Tese de Doutorado em Educação). Faculdade de Educação da Universidade Estadual de Campinas, Campinas.

Saldaña, P. (2017, 23 de janeiro). Quase 50\% dos professores não têm formação na matéria que ensinam. Folha de São Paulo. Disponível em https://www1.folha.uol.com. br/educacao/2017/01/1852259-quase-50-dos-professores-nao-tem-formacao-namateria-que-ensinam.shtml

Silva Filho, R. L. L., Motejunas, P. R., Hipólito, O., \& Lobo, M. B. C. M. (2007). A evasão no ensino superior brasileiro. Cadernos de pesquisa, 37(132), 641-659.

Tinto, V. (1975). Dropout from higher education: A theoretical synthesis of recent research. Review of Educational Research, 45(1), 89-125.

Tinto, V. (1997). Classrooms as communities: Exploring the educational character of student persistence. The Journal of Higher Education, 68(6), 599-623.

Tinto, V. (1998). Colleges as communities: Taking research on student persistence seriously. The Review of Higher Education, 21(2), 167-177.

Tinto, V. (2006). Research and practice of student retention: What next?. Journal of College Student Retention: Research, Theory \& Practice, 8(1), 1-19.

Tinto, V. (2017). Through the eyes of students. Journal of College Student Retention: Research, Theory \& Practice, 19(3), 254-269. 
Veloso, T. C. M., \& de Almeida, E. P. (2002). Evasão nos cursos de graduação da Universidade Federal de Mato Grosso, Campus Universitário de Cuiabá-um processo de exclusão. Série-Estudos-Periódico do Programa de Pós-Graduação em Educação da $U C D B,(13), 133-148$.

Yin, R. K. (2015). Qualitative Research from start to finish. 2. ed. The Guilford Press.

\section{Letícia Tasca Pigosso}

(1)

https://orcid.org/0000-0003-4377-7883 Universidade Federal do Rio Grande do Sul Instituto de Física Porto Alegre, Rio Grande do Sul, Brasil letitascap@hotmail.com

\section{Bruna Schons Ribeiro}

https://orcid.org/0000-0001-6878-4612 Universidade Federal do Rio Grande do Sul Instituto de Física Porto Alegre, Rio Grande do Sul, Brasil b.sribeiro@hotmail.com

\section{Leonardo Albuquerque Heidemann}

https://orcid.org/0000-0001-5143-6275 Universidade Federal do Rio Grande do Sul

Instituto de Física Porto Alegre, RS, Brasil leonardo.h@ufrgs.br

Submetido em 12 de dezembro de 2019 Aceito em 27 de março de 2020 Publicado em 28 de abril de 2020 


\section{Apêndice A}

O quadro abaixo sintetiza o guia das entrevistas realizadas. Como elas foram semiestruturadas, outras perguntas também foram feitas em função das respostas dos entrevistados. A ordem das perguntas não necessariamente reflete a ordem com que elas estão aqui apresentadas. Optamos, no quadro a seguir, por expor as questões organizadas em função dos construtos que se desejava investigar.

\begin{tabular}{|c|c|}
\hline Construto & Perguntas \\
\hline $\begin{array}{l}\text { Qualidade de } \\
\text { Escolha }\end{array}$ & $\begin{array}{l}\text { 1. O que te levou a escolher o curso de Licenciatura em Física? } \\
\text { 2. E por que você optou por realizá-lo na UFRGS? }\end{array}$ \\
\hline $\begin{array}{l}\text { Identificação } \\
\text { com a Profissão }\end{array}$ & $\begin{array}{l}\text { 3. O que, para você, é ser professor? } \\
\text { 4. Como você classifica um bom professor? Você se enquadra nesses critérios? }\end{array}$ \\
\hline $\begin{array}{l}\text { Experiência } \\
\text { geral do curso }\end{array}$ & $\begin{array}{l}\text { 5. Conta-me um pouco da tua experiência dentro do curso. } \\
\text { 6. O que você considera como os pontos positivos e os negativos da tua experiência } \\
\text { no curso? Por quê? } \\
\text { 7. Durante o tempo em que esteve cursando licenciatura, você contava com algum } \\
\text { tipo de auxílio estudantil? Que tipo? Se sim, qual a relevância desse auxílio na tua } \\
\text { formação? } \\
\text { 8. Você já pensou em desistir do curso? [se sim, continuam as perguntas] } \\
\text { 9. Quantas vezes? } \\
\text { 10. Você se lembra em quais semestres? } \\
\text { 11. E o que te levou a esse pensamento? } \\
\text { 12. Qual foi o principal motivo da tua persistência? } \\
\text { 13. Das pessoas que entraram contigo, você saberia me dizer quantas continuam } \\
\text { ou já se formaram na licenciatura em física? } \\
\text { 14. Em comparação aos teus colegas que desistiram, o que você acha que aconteceu } \\
\text { de diferente com você? } \\
\text { 15. E por que você acha que eles evadiram? }\end{array}$ \\
\hline $\begin{array}{l}\text { Senso de } \\
\text { Pertencimento }\end{array}$ & $\begin{array}{l}\text { 16. Como você avalia a sua relação com os professores? } \\
\text { 17. E com os colegas? } \\
\text { 18. Essa relação se dava como? (e.g. apenas dentro da universidade) } \\
\text { 19. Você teve algum tipo de bolsa ou participou de algum projeto dentro da } \\
\text { UFRGS? Qual? }\end{array}$ \\
\hline
\end{tabular}




\begin{tabular}{|l|l|}
\hline Construto & Perguntas \\
\hline $\begin{array}{l}\text { Crenças de } \\
\text { Autoeficácia }\end{array}$ & $\begin{array}{l}\text { 20. Como tu avalia o teu desempenho dentro dessa bolsa/projeto? [relacionado } \\
\text { com a pergunta 19] Quais foram as suas dificuldades ou deficiências em termos } \\
\text { 21. Você considera que essas deficiências te trouxeram empecilhos na tua formação } \\
\text { acadêmica? Que tipo? } \\
\text { 22. Fala-me um pouco da tua rotina de estudos. } \\
\text { 23. Como você construiu essa rotina de estudos? }\end{array}$ \\
\hline $\begin{array}{l}\text { Percepção de } \\
\text { Currículo }\end{array}$ & $\begin{array}{l}\text { 24. Quais foram as disciplinas que você mais gostou? E quais menos gostou? Por } \\
\text { 2uê? } \\
\text { 26. O que você pensa sobre as disciplinas que cursou? Elas foram suficientes para } \\
\text { a demanda da profissão? } \\
\text { 27. E a ordem em que essas disciplinas foram feitas? Você mudaria algo? }\end{array}$ \\
\hline
\end{tabular}

\section{Apêndice B}

O quadro abaixo sintetiza a análise de dados realizada. Para cada um dos participantes, distribuídos nas linhas do quadro, expomos elementos que os motivaram para persistir ou que contribuíram para cogitarem a desistência do curso de graduação. Os nomes de cada entrevistado foram substituídos por nomes fictícios, a fim de manter o sigilo sobre suas identidades.

\begin{tabular}{|c|c|c|c|c|}
\hline & $\begin{array}{l}\text { Passou por } \\
\text { momentos em } \\
\text { que pensou } \\
\text { seriamente em } \\
\text { evadir? }\end{array}$ & $\begin{array}{l}\text { Elementos que } \\
\text { contribuíram para } \\
\text { atenuar sua motivação } \\
\text { para persistir }\end{array}$ & $\begin{array}{l}\text { Elementos que } \\
\text { contribuíram para } \\
\text { reforçar sua motivação } \\
\text { para persistir }\end{array}$ & $\begin{array}{l}\text { Elementos que } \\
\text { poderiam ter } \\
\text { contribuído para } \\
\text { fomentar sua } \\
\text { motivação para } \\
\text { persistir }\end{array}$ \\
\hline João & Não. & $\begin{array}{l}\text { Senso de } \\
\text { pertencimento } \\
\text { desfavorável, por } \\
\text { passar pouco tempo } \\
\text { com os colegas, e } \\
\text { percepção de currículo } \\
\text { desfavorável, por } \\
\text { pensar não estar sendo } \\
\text { preparado para a } \\
\text { escola. }\end{array}$ & $\begin{array}{l}\text { Identificação com a } \\
\text { futura profissão de } \\
\text { professor, pois, apesar } \\
\text { de não sentir que estava } \\
\text { sendo preparado pelo } \\
\text { curso, já exercia a } \\
\text { profissão e precisava do } \\
\text { diploma para continuar } \\
\text { exercendo. }\end{array}$ & $\begin{array}{l}\text { Valorização da } \\
\text { Licenciatura. }\end{array}$ \\
\hline
\end{tabular}




\begin{tabular}{|c|c|c|c|c|}
\hline & $\begin{array}{l}\text { Passou por } \\
\text { momentos em } \\
\text { que pensou } \\
\text { seriamente em } \\
\text { evadir? }\end{array}$ & $\begin{array}{l}\text { Elementos que } \\
\text { contribuíram para } \\
\text { atenuar sua motivação } \\
\text { para persistir }\end{array}$ & $\begin{array}{l}\text { Elementos que } \\
\text { contribuíram } \\
\text { para reforçar sua } \\
\text { motivação para } \\
\text { persistir }\end{array}$ & $\begin{array}{l}\text { Elementos que } \\
\text { poderiam ter } \\
\text { contribuído para } \\
\text { fomentar sua } \\
\text { motivação para } \\
\text { persistir }\end{array}$ \\
\hline Júlio & $\begin{array}{l}\text { Sim. E } \\
\text { efetivamente } \\
\text { evadiu para o } \\
\text { Bacharelado } \\
\text { em Física, } \\
\text { retornando } \\
\text { posteriormente } \\
\text { para o curso de } \\
\text { Licenciatura. }\end{array}$ & $\begin{array}{l}\text { Percepção de currículo } \\
\text { desfavorável, por } \\
\text { entender que o } \\
\text { currículo não estava } \\
\text { o preparando para a } \\
\text { escola. }\end{array}$ & $\begin{array}{l}\text { Identificação com a } \\
\text { futura profissão de } \\
\text { professor, pois tinha } \\
\text { muita vontade de ser } \\
\text { professor e, para isso, } \\
\text { precisava concluir } \\
\text { o curso. Tomou } \\
\text { gosto pela profissão } \\
\text { em um projeto de } \\
\text { extensão quando } \\
\text { estava cursando o } \\
\text { Bacharelado em } \\
\text { Física. }\end{array}$ & $\begin{array}{l}\text { Contato com } \\
\text { disciplinas do } \\
\text { Ensino de Física no } \\
\text { início do curso. }\end{array}$ \\
\hline Gustavo & $\begin{array}{l}\text { Sim. E } \\
\text { efetivamente } \\
\text { evadiu, } \\
\text { retornando } \\
\text { ao curso } \\
\text { anos mais } \\
\text { tarde, quando } \\
\text { novamente } \\
\text { passou por } \\
\text { momentos em } \\
\text { que pensou em } \\
\text { evadir. }\end{array}$ & $\begin{array}{l}\text { Evasão explicada por } \\
\text { motivos externos ao } \\
\text { contexto universitário } \\
\text { (proposta de trabalho } \\
\text { em outra cidade). No } \\
\text { retorno, as crenças } \\
\text { de autoeficácia eram } \\
\text { desfavoráveis devido } \\
\text { a uma disciplina em } \\
\text { que havia reprovado na } \\
\text { passagem anterior pelo } \\
\text { curso e que, em seu } \\
\text { retorno, foi reprovado } \\
\text { mais uma vez. }\end{array}$ & $\begin{array}{l}\text { Senso de } \\
\text { pertencimento } \\
\text { à Universidade } \\
\text { foi o motivo pelo } \\
\text { qual retornou e } \\
\text { persistiu. O apoio } \\
\text { dos colegas (senso } \\
\text { de pertencimento } \\
\text { social) foi o elemento } \\
\text { mais relevante. }\end{array}$ & $\begin{array}{l}\text { Melhor suporte por } \\
\text { parte do Instituto de } \\
\text { Física. }\end{array}$ \\
\hline Vicente & $\begin{array}{l}\text { Não. Ingressou } \\
\text { no curso de } \\
\text { Bacharelado } \\
\text { em Física e } \\
\text { passou a cursar } \\
\text { Licenciatura } \\
\text { na busca de } \\
\text { estabilidade } \\
\text { profissional. }\end{array}$ & $\begin{array}{l}\text { Senso de } \\
\text { pertencimento, } \\
\text { devido a não se sentir } \\
\text { acolhido pelos seus } \\
\text { colegas e por não ter } \\
\text { realizado nenhum } \\
\text { tipo de atividade } \\
\text { extracurricular. }\end{array}$ & $\begin{array}{l}\text { Crença de } \\
\text { autoeficácia, pois, por } \\
\text { não ter enfrentado } \\
\text { dificuldades na } \\
\text { compreensão } \\
\text { dos conteúdos } \\
\text { curriculares, não } \\
\text { se viu motivado a } \\
\text { evadir. }\end{array}$ & $\begin{array}{l}\text { O construto com } \\
\text { nível mais baixo } \\
\text { é o senso de } \\
\text { pertencimento, por } \\
\text { isso o que poderia } \\
\text { ter ajudado na sua } \\
\text { motivação é ter mais } \\
\text { amigos próximos e } \\
\text { mais contato com os } \\
\text { professores. }\end{array}$ \\
\hline
\end{tabular}




\begin{tabular}{|c|c|c|c|c|}
\hline & $\begin{array}{l}\text { Passou por } \\
\text { momentos } \\
\text { em que } \\
\text { pensou } \\
\text { seriamente } \\
\text { em evadir? }\end{array}$ & $\begin{array}{l}\text { Elementos que } \\
\text { contribuíram } \\
\text { para atenuar sua } \\
\text { motivação para } \\
\text { persistir }\end{array}$ & $\begin{array}{l}\text { Elementos que } \\
\text { contribuíram para } \\
\text { reforçar sua motivação } \\
\text { para persistir }\end{array}$ & $\begin{array}{l}\text { Elementos que } \\
\text { poderiam ter } \\
\text { contribuído para } \\
\text { fomentar sua } \\
\text { motivação para } \\
\text { persistir }\end{array}$ \\
\hline Júlia & Não. & $\begin{array}{l}\text { Crenças de } \\
\text { autoeficácia (no } \\
\text { começo do curso), } \\
\text { por ter sido reprovada } \\
\text { em disciplinas e } \\
\text { ter dificuldades em } \\
\text { estudar. }\end{array}$ & $\begin{array}{l}\text { Senso de pertencimento, } \\
\text { por ter feito muitos } \\
\text { amigos ao longo do } \\
\text { curso e participado } \\
\text { de diversas atividades } \\
\text { extracurriculares. } \\
\text { Identificação com a } \\
\text { profissão também é } \\
\text { relevante, pois, desde o } \\
\text { princípio, desejava ser } \\
\text { professora. }\end{array}$ & $\begin{array}{l}\text { Menos "terror } \\
\text { psicológico" } \\
\text { por parte dos } \\
\text { professores e } \\
\text { mais disciplinas } \\
\text { específicas da área } \\
\text { de Ensino de Física } \\
\text { no começo do } \\
\text { curso. }\end{array}$ \\
\hline Enzo & Não. & $\begin{array}{l}\text { Todos os construtos } \\
\text { do modelo de } \\
\text { Tinto (senso de } \\
\text { pertencimento, } \\
\text { crenças de autoeficácia } \\
\text { e percepção de } \\
\text { currículo) são } \\
\text { medianos. Nenhum } \\
\text { foi responsável } \\
\text { por atenuar sua } \\
\text { motivação. }\end{array}$ & $\begin{array}{l}\text { Percepção de currículo, } \\
\text { que começou a se } \\
\text { tornar relevante com as } \\
\text { disciplinas de específicas } \\
\text { da área de Ensino de } \\
\text { Física, fazendo-o se } \\
\text { sentir pertencente ao } \\
\text { Instituto de Física e a se } \\
\text { identificar com a futura } \\
\text { profissão de professor. O } \\
\text { senso de pertencimento } \\
\text { foi relevante também a } \\
\text { partir da participação } \\
\text { em bolsa de iniciação } \\
\text { científica. }\end{array}$ & $\begin{array}{l}\text { Disciplinas } \\
\text { específicas sobre } \\
\text { o Ensino de Física } \\
\text { no começo do } \\
\text { curso. }\end{array}$ \\
\hline Caroline & $\begin{array}{l}\text { Sim. Em duas } \\
\text { situações: } \\
\text { uma entre } \\
\text { o quarto } \\
\text { e o quinto } \\
\text { semestre de } \\
\text { curso e outra } \\
\text { no último } \\
\text { semestre. }\end{array}$ & $\begin{array}{l}\text { Os três construtos } \\
\text { somados, pois } \\
\text { no momento em } \\
\text { que o senso de } \\
\text { pertencimento } \\
\text { diminuiu } \\
\text { consequentemente } \\
\text { diminuiu a crença } \\
\text { de autoeficácia e } \\
\text { tornou a percepção de } \\
\text { currículo pior. }\end{array}$ & $\begin{array}{l}\text { Percepção de currículo, } \\
\text { que começou a ser } \\
\text { relevante no quinto } \\
\text { semestre, de modo } \\
\text { que ela passou a ver a } \\
\text { Licenciatura como algo } \\
\text { nobre e que ela poderia } \\
\text { seguir. }\end{array}$ & $\begin{array}{l}\text { Mais disciplinas } \\
\text { específicas sobre } \\
\text { o Ensino de Física } \\
\text { no começo do } \\
\text { curso. }\end{array}$ \\
\hline
\end{tabular}




\begin{tabular}{|c|c|c|c|c|}
\hline & $\begin{array}{l}\text { Passou por } \\
\text { momentos } \\
\text { em que } \\
\text { pensou } \\
\text { seriamente } \\
\text { em evadir? }\end{array}$ & $\begin{array}{l}\text { Elementos que } \\
\text { contribuíram } \\
\text { para atenuar sua } \\
\text { motivação para } \\
\text { persistir }\end{array}$ & $\begin{array}{l}\text { Elementos que } \\
\text { contribuíram para } \\
\text { reforçar sua motivação } \\
\text { para persistir }\end{array}$ & $\begin{array}{l}\text { Elementos que } \\
\text { poderiam ter } \\
\text { contribuído para } \\
\text { fomentar sua } \\
\text { motivação para } \\
\text { persistir }\end{array}$ \\
\hline César & Não. & $\begin{array}{l}\text { Apesar de todos } \\
\text { os construtos de } \\
\text { Tinto se mostrarem } \\
\text { desfavoráveis, } \\
\text { nenhum elemento } \\
\text { causou incômodo ao } \\
\text { entrevistado. }\end{array}$ & $\begin{array}{l}\text { Crenças de autoeficácia, } \\
\text { pois não enfrentou } \\
\text { dificuldades de } \\
\text { compreensão dos } \\
\text { conteúdos curriculares. }\end{array}$ & $\begin{array}{l}\text { Não foi possível } \\
\text { identificar } \\
\text { elementos que } \\
\text { poderiam ter o } \\
\text { motivado mais. } \\
\text { Cabe destacar } \\
\text { que, se o currículo } \\
\text { exigisse maior } \\
\text { contato com a } \\
\text { escola desde o } \\
\text { início do curso, } \\
\text { provavelmente } \\
\text { ele teria evadido. } \\
\text { Passou a cursar } \\
\text { o Bacharelado } \\
\text { em Física após a } \\
\text { diplomação. }\end{array}$ \\
\hline Vitória & $\begin{array}{l}\text { Sim. Em duas } \\
\text { situações: } \\
\text { uma no } \\
\text { início do } \\
\text { curso e outra } \\
\text { no terceiro } \\
\text { semestre. }\end{array}$ & $\begin{array}{l}\text { Crenças de } \\
\text { autoeficácia, por sentir } \\
\text { que não seria capaz } \\
\text { de suprir as demandas } \\
\text { das disciplinas } \\
\text { iniciais. }\end{array}$ & $\begin{array}{l}\text { Percepção de currículo, } \\
\text { pois nos momentos } \\
\text { em que ela não via } \\
\text { perspectivas no curso, } \\
\text { ela lembrava que em } \\
\text { certo tempo cursaria } \\
\text { disciplinas em que via } \\
\text { sentido, que eram as } \\
\text { disciplinas específicas } \\
\text { da área de Ensino de } \\
\text { Física. }\end{array}$ & $\begin{array}{l}\text { Contato com } \\
\text { disciplinas } \\
\text { específicas da } \\
\text { área de Ensino de } \\
\text { Física no início do } \\
\text { curso. }\end{array}$ \\
\hline Vitor & Não. & $\begin{array}{l}\text { Senso de } \\
\text { pertencimento, } \\
\text { pois não se sentia } \\
\text { pertencente ao } \\
\text { Instituto de Física, } \\
\text { nem se identificava } \\
\text { com a profissão de } \\
\text { professor de Física, } \\
\text { por estar mais } \\
\text { engajado na Faculdade } \\
\text { de Educação. }\end{array}$ & $\begin{array}{l}\text { Crenças de autoeficácia, } \\
\text { pois sempre acreditava } \\
\text { ser capaz de concluir } \\
\text { o curso, e senso } \\
\text { de pertencimento, } \\
\text { por fazer atividades } \\
\text { extracurriculares desde } \\
\text { o início do curso. }\end{array}$ & $\begin{array}{l}\text { Contato com } \\
\text { disciplinas } \\
\text { específicas da } \\
\text { área de Ensino de } \\
\text { Física no início } \\
\text { do curso e ter a } \\
\text { possibilidade de } \\
\text { realizar iniciação } \\
\text { científica no } \\
\text { Instituto de } \\
\text { Física. }\end{array}$ \\
\hline
\end{tabular}




\begin{tabular}{|c|c|c|c|c|}
\hline & $\begin{array}{l}\text { Passou por } \\
\text { momentos } \\
\text { em que } \\
\text { pensou } \\
\text { seriamente } \\
\text { em evadir? }\end{array}$ & $\begin{array}{l}\text { Elementos que } \\
\text { contribuíram } \\
\text { para atenuar sua } \\
\text { motivação para } \\
\text { persistir }\end{array}$ & $\begin{array}{l}\text { Elementos que } \\
\text { contribuíram para } \\
\text { reforçar sua motivação } \\
\text { para persistir }\end{array}$ & $\begin{array}{l}\text { Elementos que } \\
\text { poderiam ter } \\
\text { contribuído para } \\
\text { fomentar sua } \\
\text { motivação para } \\
\text { persistir }\end{array}$ \\
\hline Maria & Não. & $\begin{array}{l}\text { Crença de autoeficácia } \\
\text { gerou alguns } \\
\text { momentos de recaída, } \\
\text { pois nas disciplinas de } \\
\text { Física e Matemática } \\
\text { pensava que não seria } \\
\text { capaz de suprir as } \\
\text { demandas necessárias } \\
\text { para ser aprovada. }\end{array}$ & $\begin{array}{l}\text { Senso de pertencimento, } \\
\text { pois sempre teve } \\
\text { amigos dentro da } \\
\text { universidade que a } \\
\text { motivaram, e a mudança } \\
\text { da identificação com } \\
\text { a profissão gerada } \\
\text { pelo pertencimento } \\
\text { ao Instituto de Física } \\
\text { (devido principalmente } \\
\text { às disciplinas específicas } \\
\text { da área de Ensino de } \\
\text { Física). }\end{array}$ & $\begin{array}{l}\text { Participação em } \\
\text { bolsas de iniciação } \\
\text { a docência. }\end{array}$ \\
\hline Bruno & $\begin{array}{l}\text { Sim. Em três } \\
\text { ocasiões: } \\
\text { No terceiro } \\
\text { semestre e } \\
\text { no quinto } \\
\text { semestre de } \\
\text { curso estava } \\
\text { desacreditado } \\
\text { com relação à } \\
\text { profissão, e no } \\
\text { sexto semestre } \\
\text { não acreditava } \\
\text { que seria capaz } \\
\text { de se formar. }\end{array}$ & $\begin{array}{l}\text { Identificação com } \\
\text { a profissão, pois } \\
\text { inicialmente não sentia } \\
\text { que gostaria de ser } \\
\text { professor e também não } \\
\text { sentia que seria um bom } \\
\text { professor. }\end{array}$ & $\begin{array}{l}\text { Senso de Pertencimento, } \\
\text { gerado pela relação que } \\
\text { possuía com colegas, } \\
\text { professores e com as } \\
\text { atividades experimentais. }\end{array}$ & $\begin{array}{l}\text { Contato com } \\
\text { disciplinas } \\
\text { específicas da área } \\
\text { de Ensino de Física } \\
\text { mais cedo e contato } \\
\text { com alunos. }\end{array}$ \\
\hline
\end{tabular}

